Volume 3 Issue 1 (2019) Pages 110 - 116

Jurnal Obsesi : Jurnal Pendidikan Anak Usia Dini

DOI: $10.31004 /$ obsesi.v3i1.106

\title{
Penanaman Pendidikan Karakter pada Model Pembelajaran BCCT (Beyond Centers and Circle Time)
}

\author{
Veny Iswantiningtyas ${ }^{1 凶}$, Widi Wulansari $^{2}$ \\ Prodi. Pendidikan Guru Pendidikan Anak Usia Dini \\ Fakultas Keguruan dan Ilmu Pendidikan - Universitas Nusantara PGRI Kediri
}

\begin{abstract}
This study aims to determine the learning process of early childhood education through the learning model of BCCT (Beyond Centers and Circle Time) in instilling character education in Tauladan Kindergarten and Pare District, Kediri Regency. The type of research used is qualitative with an ethnographic approach. Selection of subjects using purposive sampling, followed by Snow Ball Sampling. Data collection in this study uses methods of observation, interviews and documentation. The success of planting character education through the BCCT (Beyond Centers and Circle Time) learning model can be seen by looking at the results of the assessment that has been done by the teacher.
\end{abstract}

Keywords: character education planting, BCCT learning model

\begin{abstract}
Abstrak
Penelitian ini bertujuan untuk mengetahui proses pembelajaran pendidikan anak usia dini melalui model pembelajaran BCCT (Beyond Centers and Circle Time) dalam menanamkan pendidikan karakter di Taman Kanak-Kanak Tauladan Kecamatan Pare Kabupaten Kediri. Jenis penelitian yang digunakan adalah kualitatif dengan pendekatan etnografi. Pemilihan subyek menggunakan purposive sampling, dilanjutkan dengan Snow Ball Sampling. Pengumpulan data pada penelitian ini menggunakan metode observasi, wawancara dan dokumentasi. Keberhasilan penanaman pendidikan karakter melalui model pembelajaran BCCT (Beyond Centers and Circle Time) dapat diketahui dengan melihat hasil penilaian yang telah dilakukan oleh guru.
\end{abstract}

Kata Kunci: penanaman pendidikan karakter, model pembelajaran BCCT

@ Jurnal Obsesi Prodi PG-PAUD FIP UPTT 2019

$\triangle$ Corresponding author:

Address : Universitas Nusantara PGRI Kediri

ISSN 2356-1327 (Media Cetak)

Email : veny@unpkediri.ac.id

ISSN 2549-8959 (Media Online) 


\section{PENDAHULUAN}

Pendidikan Nasional bertujuan untuk mengembangkan dan membentuk watak serta peradaban bangsa yang bermartabat dalam rangka mencerdasakan kehidupan bangsa, serta mengembangkan peserta didik agar menjadi manusia yang beriman dan bertaqwa kepada Tuhan Maha Esa, berakhak mulia, sehat bermulia, cakap, kreatif, mandiri dan bertanggung jawab. Menurut Wibowo, ruang lingkup kurikulum di Taman Kanak-kanak dan RA diarahkan pada aspek perkembangan anak usia dini diantaranya: 1) moral dan nilai-nilai agama, 2) sosial emosional dan kemandirian, 3) kemampuan berbahasa, 4) kognitif, 5) fisik dan motorik, 6) seni budaya (Wibowo, 2012). Berdasarkan Standar Kompetensi tersebut, maka menumbuhkan karakter anak usia sejak di PAUD adalah langkah yang tepat. Melalui langkah tersebut diharapkan karakter sudah menjadi bagian dari diri anak usia dini.

Ruqoyah menjelaskan bahwa untuk meningkatkan mutu pendidikan anak usia dini pemerintah menerapkan salah satu program yang dinamakan program pendidikan karakter. Program pendidikan karakter menerapkan beberapa aspek penanaman pengetahuan, kecintaan dan penanaman perilaku kebaikan menjadi sebuah pola/kebiasaan (Ruqoyah, 2016). Pandangan Ki Hajar Dewantara terkait pendidikan karakter antara lain: 1) pendidikan karakter merupakan salah satu bagian yang tidak terpisahkan dalam sistem pendidikan nasional yang diberikan sejak usia 4-21 tahun; 2) Pendidikan karakter membentuk mental atau sikap yang baik dan menghilangkan mental atau perilaku buruk (sikap jujur, disiplin, bertanggung jawab, demokratis, tidak mementingkan diri sendiri, berani, rela berkorban, tidak merusak, tidak menyakiti orang lain, hidup sehat dan bersih, hormat kepada orang tua, toleran, empati, dan cinta tanah air; 3) pendidikan karakter bagi anak usia dini dapat dilakukan terutama oleh orang tua dan guru melalui pembiasaan atau percontohan dalam berbagai kegiatan pembelajaran bercerita, menggambar, bermain dengan alat permainan tradisional, menyulam, bernyanyi (Maspinal, 2013).

Hasil penelitian yang telah dilakukan oleh Ruqoyah menyebutkan bahwa pada saat ini model pembelajaran pendidikan anak usia dini masih didominasi oleh pembelajaran yang berpusat pada guru. Untuk meningkatkan efisiensi pembelajaran, pemerintah mengadopsi salah satu model pembelajaran yaitu model pembelajaran BCCT (Beyond Centers and Circle Time) (Ruqoyah, 2016). Lebih lanjut, Palupi menjelaskan bahwa BCCT atau Beyond Centers and Circle Time merupakan metode pembelajaran yang sering disebut SELI atau Sentra dan Lingkaran. Metode ini merupakan pengembangan dari metode Montessori, High Scope dan Reggio Emilio yang dikembangkan oleh CCCRT atau Creative Center for Childhood Research and Training, Florida, USA dimana konsep belajarnya guru menghadirkan dunia nyata dalam kelas untuk mendorong muridmuridnya membuat hubungan antara pengetahuan yang dimiliki dengan penerapannya di kehidupan sehari-hari (Samad \& Alhadad, 2016). Lebih lanjut Sujiono menjelaskan bahwa model pembelajaran BCCT (Beyond Centers and Circle Time) adalah suatu metode atau pendekatan dalam penyelenggaraan pendidikan anak usia dini yang merupakan perpaduan antara teori dan praktik (Sujiono, 2009).

Tujuan pendekatan dari $B B C T$ atau Beyond Center and Circle Time yaitu : 1) Melejitkan potensi kecerdasan anak : kecerdasan sebagai kemampuan untuk mememcahkan masalah dan menciptakan 
produk yang mempunyai nilai buadaya; 2) Penanaman nilai-nilai dasar ; anak merupakan individu yang baru menggenal dunia dan belum mengetahui tata krama, sopan santun, aturan, norma dan sebagainya. Anak perlu dibimbing agar mampu memahami berbagai hal. Usia dini merupakan saat yang sangat berharga untuk menananamkan nilai-nilai dasar dalam kehidupan yang meliputi: nilai-nilai nasionalisme, nilai-nilai agama, nilai-nilai etika, nilai-nilai moral dan nilai-nilai sosial; 3) pengembangan kemampuan dasar (Samad \& Alhadad, 2016).

Menurut Latif $\mathrm{dkk}$, terdapat tujuh sentra yang dikembangkan oleh Dr. Pamela Phelps, yaitu 1) sentra persipan, 2) sentra balok, 3) sentra peran besar, 4) sentra peran kecil, 5) sentra bahan alam, 6) sentra seni dan 7) sentra musik. Kemudian di Indonesia dikembangkan menjadi enam sentra yaitu: 1) sentra persiapan, 2) sentra balok, 3) sentra bahan alam, 4) sentra seni, 5) sentra main peran besar dan 6) sentra main peran kecil (Latif, Zulkhairina, Zubaidah, \& Muhammad Afandi, 2013). Sedangkan menurut Kusumandari dan Istyarini, implementasi pendidikan karakter melalui pembelajaran e-learning dan berbagai kecerdasan dapat menggunakan 10 sentra, yaitu: 1) sentra pusat persiapan, 2) sentra persiapan, 3) sentra alam padat, 4) sentra alam cair, 5) sentra IMTAQ, 6) sentra balok, 7) sentra main peran, 8) sentra bahasa Inggris, 9) sentra seni, dan 10) sentra tubuh (Kusumandari \& Istyarini, 2015).

Permasalahan pendidikan karakter di Indonesia, dilihat dari sudut pandang peneliti perlu adanya model pembelajaran yang mampu menanamkan pendidikan karakter pada anak usia dini. Di dalam penelitian ini, akan dibahas penggunaan metode pembelajaran BCCT untuk menanamkan nilai-nilai pendidikan karakter anak usia dini. Menurut Istiqomah, metode
BCCT ini diyakini mampu merangsang seluruh aspek kecerdsasan anak melalui bermain yang terarah, setting pembelajaran yang mampu merangsang anak selalu aktif, kreatif, dan terus berpikir dengan menggali pengalamannya sendiri. Anak didorong untuk bermain di sentra-sentra kegiatan, sedangkan pendidik berfungsi sebagai perancang, pendukung, dan penilai kegiatan anak. Pembelajarannya bersifat individual, sehingga rancangan, dukungan, dan penilaiannya pun disesuaikan dengan tingkat perkembangan kebutuhan setiap anak (Ma'rifah \& Muthmainnah, 2015). Oleh sebab itu, dilakukan penelitian untuk mendeskripsikan penggunaan model pembelajaran BCCT dalam menanamkan pendidikan karakter bagi anak usia dini.

\section{METODOLOGI}

Jenis penelitian yang digunakan adalah kualitatif dengan pendekatan etnografi. Adapun tujuan yang hendak dicapai yaitu untuk menjelaskan dan menganalisis kondisi pembelajaran dengan menggunakan metode pembelajaran sentra dalam menanamkan nilai-nilai karakter di Taman Kanak-kanak Tauladan Kecamatan Pare Kabupaten Kediri pada tahun pelajaran 2017/2018. Pemilihan subyek dalam penelitian ini menggunakan purposive sampling, dilanjutkan dengan menggunakan Snow Ball Sampling (Patilima, 2010), yaitu pemilihan sample dengan pertimbangan 1) subyek penelitian adalah anak usia dini yang terlibat langsung dalam proses pembelajaran dengan metode sentra, 2) informan dalam penelitian ini merupakan pihak yang menguasai permasalahan berkenan memberikan informasi dan data yaitu guru dan kepala sekolah TK Tauladana Pare.

Penggalian informasi pada penelitian ini menggunakan metode observasi, wawancara dan dokumentasi. Metode 
observasi digunakan untuk mengamati proses belajar mengajar yang berlangsung dengan menerapkan metode sentra dalam menanamkan pendidikan sentra. Pada kegiatan ini, peneliti menggunakan panduan observasi dan catatan lapangan sesuai dengan kegiatan yang diteliti. Metode wawancara pada subyek penelitian untuk mengetahui bagaimana penerapan metode sentra dalam menanamkan nilainilai pendidikan karakter. Metode Dokumentasi yakni mnengumpulkan dokumen-dokumen RPPM / Rencana Pelaksanaan Pembelajaran Mingguan dan RPPH / Rencana Pelaksanaan Pembelajaran Harian tentang nilai-nilai penidikan karakter di Taman Kanak-kanak Tauladan Kecamatan Pare Kabupaten Kediri.

\section{HASIL DAN PEMBAHASAN}

Pada awal tahun ajaran baru sekolah selalu menyusun rencana pembelajaran berupa program tahunan, program semester, rencana program pembelajaran mingguan dan rencana program pembelajaran harian yang disesuaikan dengan tema, subtema, aspek-aspek kemampuan anak dan nilainilai pendidikan karakter. Hal ini sesuai dengan perencanaan yang dilakukan oleh Taman Kanak-kanak Tauladan Kecamatan Pare Kabupaten Kediri. Kegiatan pembelajaran di TK Tauladan ini menerapkan model pembelajaran BCCT atau sering disebut model pembelajaran sentra. Pada TK ini menggunakan tujuh (7) sentra, yang terdiri dari: 1) sentra persiapan, 2) sentra balok, 3) sentra main peran, 4) sentra seni kreativitas, 5) sentra masak, 6) sentra bahan alam, dan 7) sentra musik. Kegiatan pembelajaran terbagi menjadi tiga, yaitu: kegiatan awal, kegiatan inti dan kegiatan penutup.

Kegiatan awal merupakan rangkaian aktivitas yang menarik dan menyenangkan bagi anak dimulai dari anak datang ke sekolah disambut guru, kemudian anak diajak guru untuk berbaris di halaman sekolah, salah seorang guru mememimpin dan guru lain beserta peserta didik mengikuti gerakan mootik kasar dan bernyanyi, kegiatan ini berlangsung kurang lebih 25 menit. Setelah kegiatan awal selesai semua murid berbaris membentuk kereta-keretan mengikuti guru untuk masuk kelas sentra.

Kegiatan Inti merupakan kegiatan pembelajaran di sentra. Sebelum masuk di kegiatan inti guru dan peserta didik duduk melingkar, guru memberikan salam kepada semua peserta didik, guru mengabsen peserta didik, guru meminta peserta didik untuk memperhatikan siapa yang tidak hadir, berdoa bersama, guru menyampaikan tema kegiatan pembelajaran yang akan dilakukan sesuai dengan kehidupan seharihari, guru mengenalkan semua alat permainan yang telah dipersipakan dan menceritakan permainan yang akan dilakukan oleh peserta didik, guru menyampaikan aturan main, setelah peserta didik siap bermain, guru mempersilakan peserta didik untuk main. Guru berkeliling di antara peserta didik yang bermain yakni memberikan contoh cara bermain bagi peserta didik yang belum mampu dan memberikan pujian pada permainan yang telah dilakukan, selain itu guru juga mencatat hasil perkembangan peserta didik dan mengumpulkan hasil karya peserta didik selama satu semester dalam partofolio.

Kegitan penutup merupakan kegiatan yang memberikan pengalaman dan mengingat kembali. Guru memberitahu kepada peserta didik 5 menit sebelum kegiatan berakhir, guru memberitahu saatnya membereskan semua alat main, apabila peserta didik sudah merapikan alat main, peserta didik dan guru duduk melingkar, guru menanyakan pada setiap peserta didik tentang kegiatan main yang 
telah dilakukan / recalling, hal ini dilakukan untuk melatih daya ingat peserta didik dan pengalaman mainnya, selanjutnya guru mengajak peserta didik untukk cuci tangan, berdoa, makan siang dan pulang.

Dari hasil wawancara dan pengamatan yang telah dilakukan dapat disimpulkan bahwa pada saat kegiatan pembelajaran diawali dengan guru mensetting lingkungan main dan mengajak anak untuk melakukan kegiatan sebelum bermain. Kegiatan pembelajaran diawali dengan sapaan, nyanyian, membahas tema, dan topik. Anak bermain di area-area main yang sudah disetting oleh guru. Kegiatan diakhiri dengan kegiatan recalling, memberikan kesempatan kepada semua anak untuk menceritakan pengalaman main secara bergiliran melalui tanya jawab atau bercerita. Anak menjadi pembelajar yang aktif selama proses pembelajaran. Kegiatan disetting oleh guru melalui area main di sentra-sentra dengan konsep tematik. Adapun nilai-nilai pendidikan karakter yang ditanamkan pada sentra yaitu :

Sentra persiapan fokus pada kesempatan anak untuk mengurutkan, mengklasifikasikan, membuat pola-pola dan mengorganisasikan alat-alat dan bahan kerja, termasuk persiapan membaca, menulis dan berhitung. Adapapun nilai pendidikan karakter yang ditanamkan adalah Jujur, Gemar Membaca, Semangat Kebangsaan, Cinta Tanah Air,

Sentra balok membantu anak dalam meningkatkan kemampuan berkonstruksi mereka dari membuat susunan garis lurus ke atas ke representasi nyata dan dari bermain sendiri ke kemampuan bekerja dalam kelompok kecil, merencanakan dan membangun. Nilai pendidikan karakter yang ditanamkan yaitu disiplin dan tanggung jawab.

Sentra main peran dapat memupuk kerjasama yang baik dalam hubungan sosial, memberi kesempatan pada anak untuk melahirkan daya kerasi masingmasing, mengembangkan emosi yang sehat bagi anak-anak, menghilangkan sifat malu, gugup, dan lain-lain, mengembangkan apresiasi dan sikap yang baik, menghargai pikiran dan pendapat orang lain, menanamkan kepercayaan diri sendiri, dan dapat mengurangi kejahatan dan kenakalan anak-anak. Pendidikan karakter yang ditanamkan yaitu Bersahabat/ Komunikatif, Cinta Damai dan Peduli Sosial.

Sentra seni kreativitas memberikan pengalaman proses kerja yang bermutu, bukan menghasilkan suatu karya seni, selain itu anak mendapatkan kesenangan dari eksplorasi warna, keterampilan motorik halus dan proses kreativitas serta membangun kemampuan dasar-dasar seni. Pendidikan karakter yang ditanamkan yaitu : Kerja Keras, Kreatif, Demokratis.

Sentra masak membantu anak untuk memiliki pengalaman yang unik dalam mengenal tentang berbagai bahan makanan. Pada sentra ini anak dapat belajar tentang berbagai konsep sanis, matematika dan sosial, sehingga dapat menunjang perkembangan kognitif, bahasa, sosialemosional, motorik, agama dan seni. Adapapun nilai pendidikan karakter yang ditanamkan religius dan rasa ingin tahu.

Sentra bahan alam memberikan kesempatan untuk membangun kemampuan dengan berbagai macam bahan atau dengan bahan-bahan yang berbeda. Selain itu juga memberikan kesempatan anak mendapatkan pengalaman sensori-motor yang kaya dan mampu membangun kontrol diri. Menurut Nurani (2014) sentra bahan alam memberi kesempatan untuk melakukan bermacam kegiatan belajar sehingga dibutuhkan media pembelajaran yang bervariasi untuk mendukung proses pembelajaran. Nilai pendidikan karakter yang adalah mandiri dan peduli lingkungan. 
Sentra yang terakhir adalah sentra musik. Pada sentra musik ini, anak-anak belajar mengekplorasi berbagai alat musik maupun lagu. Musik dapat bermanfat bagi anak untuk mengembangkan keterampilan fisik dan sosial, melatih kedisiplinan, kesabaran, rasa percaya diri dan mengenalkan pada budaya lain. Nilai pendidikan karakter yang ditanamkan menghargai prestasi dan toleransi.

Pelaksanaan pendidikan karakter dapat mengintegrasikan nilai karakter yang satu dengan nilai karakter yang lainnya. Misalnya, jika nilai kesabaran dapat diterapkan dengan baik maka nilai yang lain mengikutinya karena anak yang sabar pasti akan memiliki sikap toleransi, bersahabat, peduli pada teman, dan menghargai prestasi temannya. Pengembangan masing-masing nilai karakter adalah saling mendukung, yang selanjutnya diaplikasikan dalam tiaptiap sentra. Penanaman nilai karakter dilakukan secara bertahap dengan menentukan pilihan nilai karakter yang sesuai dengan masing-masing sentra. Melalui sentra-sentra tersebut, guru juga dapat dengan mudah menanamkan dan mengamati nilai-nilai pendidikan karakter yang muncul maupun belum muncul pada anak didiknya.

Menurut hasil pengamatan yang dilakukan di TK Tauladan terlihat bahwa anak-anak sudah mampu melaksanakan pendidikan karakter dengan baik. Cara menilai dari hasil pelaksanaan pendidikan karakter yaitu melalui pengamatan yang dilakukan secara terus menerus. Terdapat beberapa kategori penilaian yang diberikan guru untuk menilai keberhasilan pendidikan karakter pada anak, antara lain: Belum Muncul, yaitu anak belum menunjukkan perilaku yang diharapkan; Mulai Muncul, yaitu anak mulai menunjukkan perilaku yang diharapkan dengan bantuan guru/orang lain; Muncul, yaitu anak menunjukkan perilaku yang diharapkan tanpa perlu diingatkan; dan Sudah Muncul, yaitu anak menunjukkan perilaku yang diharapkan dan mampu menjadi contoh bagi orang lain.

Berdasarkan hasil penelitian yang telah dilakukan dapat diketahui bahwa kedelapan belas nilai pendidikan karakter yang ditetapkan oleh Kemendikbud mampu ditanamkan dengan mudah pada anak usia dini khususnya di TK Tauladan melalui model pembelajaran sentra yang terbagi menjadi 7 sentra. Hasil penelitian ini didukung oleh beberapa penelitian yang juga menggunakan model BCCT dalam menanamkan pendidikan karakter. Pertama, penelitian Ruqoyah menunjukkan bahwa terdapat perbedaan hasil antara anak dengan kreativitas rendah dan kreativitas tinggi yang diajar dengan menggunakan model pembelajaran BCCT dan non BCCT (Ruqoyah, 2016). Kedua, penelitian Samad dan Alhadad menunjukkan bahwa penerapan metode pembelajaran sentra dalam penanaman nilai-nilai agama Islam di TK Khalifah Ternate membuat anak merasa lebih memiliki kesempatan untuk mengekspresikan bakat dan minat (Samad \& Alhadad, 2016). Ketiga, penelitian Maimunah dkk menunjukkan bahwa guru di dalam model pembelajaran sentra mempunyai peranan penting untuk membangun karakter anak melalui komunikasi positif, perancah, pembiasaan, dan konsistensi dalam membangun aturan. Aturan yang dibuat harus disesuaikan berdasarkan aktivitas dan karakter yang dikembangkan oleh sekolah (Maimunah, Aslamiah, \& Suriansyah, 2018).

\section{KESIMPULAN}

Model pembelajaran yang digunakan oleh Taman Kanak-kanak Tauladan menggunakan SELI (Metode Sentra dan Lingkaran) atau sering disebut model pembelajaran sentra. Kegiatan dimulai 
dengan jurnal pagi yang menyenangkan kemudian masuk pada kegiatan inti yakni bermain di sentra. Tema dibahas oleh guru sebelum bermain kemudian kegiatan ditutup dengan melakukan recalling, dalam proses pembelajaran yang telah dilakukan menanamkan nilai-nilai pendidikan karakter. Dengan menggunakan model pembelajaran Sentra, pendidikan karakter dapat ditanamkan pada anak usia dini dengan tepat.

\section{UCAPAN TERIMA KASIH}

$\begin{array}{cccc}\text { Kami } & \text { selaku } & \text { tim } & \text { peneliti } \\ \text { mengucapkan } & \text { terima } & \text { kasih } & \text { kepada }\end{array}$ Kemenristekdikti yang telah membiayai penelitian ini dan kepada TK Tauladan yang telah berkenan menjadi sumber data serta semua pihak yang telah membantu sehingga proses penelitian dapat berjalan dengan lancar.

\section{DAFTAR PUSTAKA}

Kusumandari, R. B., \& Istyarini, K. (2015). Character Education Development Model-based E-Learning and Multiple in Telegency in Childhood in Central Java, 15(3). Retrieved from https://www.researchgate.net/publicat ion/328852343_Character_Education _Development_Model-based_ELearning_and_Multiple_Intelegency_ in_Childhood_in_Central_Java

Latif, M., Zulkhairina, Zubaidah, R., \& Muhammad Afandi. (2013). Orientasi Baru Pendidikan Anak Usia Dini Teori dan Praktek. Jakarta: Kencana Prenada Media Grup.

Ma'rifah, U., \& Muthmainnah, A. (2015). Metode Pembelajaran BCCT dalam Mengembangkan Nilai Moral Pendidikan Karakter Anak Usia Dini. Jurnal PG-PAUD Trunojoyo, 2(2), 117-124. Retrieved from http://journal.trunojoyo.ac.id/pgpaudt runojoyo/article/view/2676
Maimunah, Aslamiah, \& Suriansyah, A. (2018). The Integration of SentraBased Learning and Involvement of Family Program at Early Childhood in Developing Character Building (Multi Case at PAUD Mawaddah and PAUD Alam Berbasis Karakter Sayang Ibu Banjarmasin, Indonesia). European Journal of Education Studies, 5(7), 49-63. https://doi.org/10.5281/zenodo.14942 07

Maspinal. (2013). Siap Menjadi Guru dan Pengelola PAUD Profesional. Jakarta: PT Elex Media Komputindo.

Nurani, Y. (2014). Kurikulum Anak Usia Dini. Program Studi PG-Pendidikan Anak Usia Dini Fakultas Pendidikan. Jakarta: Universitas Negeri Jakarta.

Patilima, H. (2010). Metode Penelitian Kualitatif. Malang: UMM Press.

Ruqoyah, A. (2016). Pengaruh Model Pembelajaran Beyond Centers and Circle Times (BCCT) dan Kemandirian Terhadap Kreativitas. Jurnal Pendidikan Usia Dini, 10(1), 81-98.

https://doi.org/https://doi.org/10.2100 9/JPUD.101.05

Samad, F., \& Alhadad, B. (2016). Implementasi Metode Beyond Center and Circle Time (BCCT) dalam Upaya Penanaman Nilai-Nilai Agama Islam di Kelompok B Taman KanakKanak Khalifah Kota Ternate. Jurnal Pendidikan Usia Dini, 10(2), 233254.

https://doi.org/https://doi.org/10.2100 9/JPUD.102.03

Sujiono, Y. N. (2009). Konsep Dasar Pendidikan Anak Usia Dini. Jakarta: Indeks.

Wibowo, A. (2012). Pendidikan Karakter Usia Dini ( Strategi Membangun Karakter di Usia Emas). Yogyakarta: Pustaka Pelajar. 